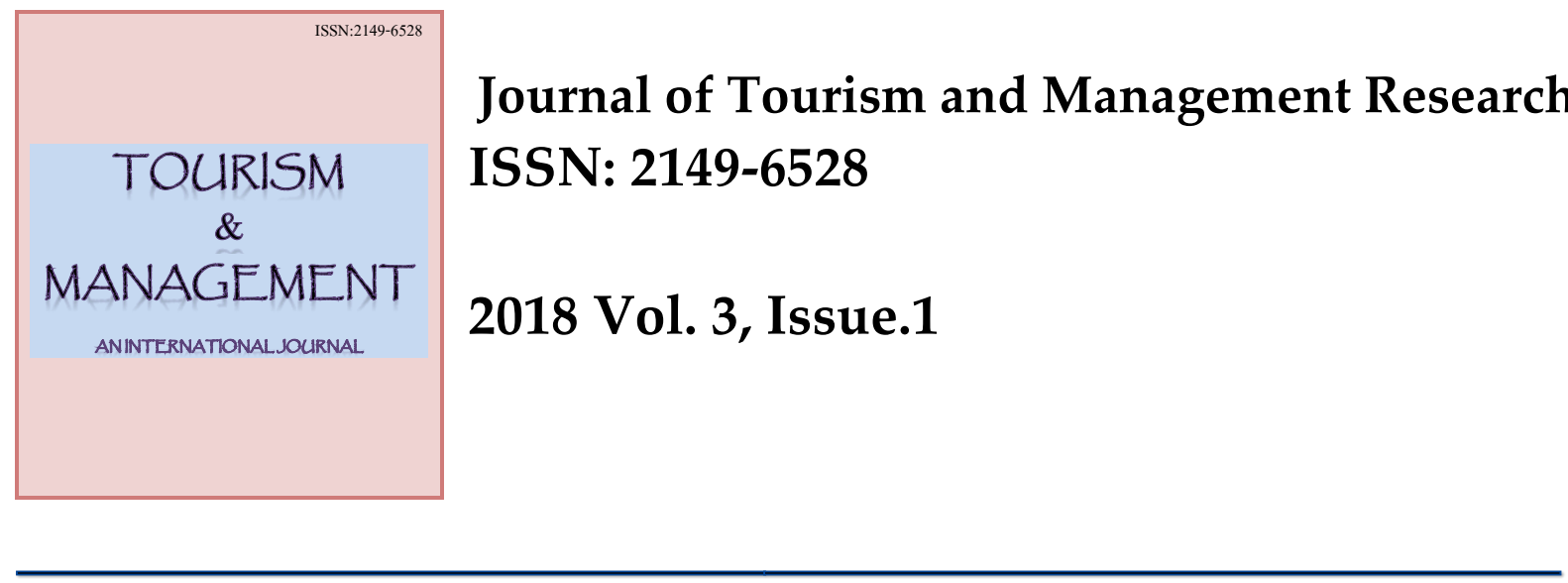

\title{
Managerial Staff Perceptions of Environmental Management Practices: A Preliminary Study from Kuala Lumpur Hotels
}

\begin{abstract}
This paper aims to explore the actual benefits of engaging Environmental Management Practices (EMPs) in hotels and identify whether it is purely a marketing strategy or an actual effort to conserve the environment. The study gathered data from primary as well as secondary sources. A qualitative approach through a structured interview was engaged for the study. The respondents were managerial staff from operational department in the selected leading hotels in Kuala Lumpur. The respondents who participated in the study were directly involved in the various EMPs. The findings revealed that EMPs were implemented in hotels to comply with the various accreditation bodies and for a better word of mouth for improved sales performance. The study can pave way for hotels to align their system and improvise their approaches toward implementing EMPs.
\end{abstract}

Keywords: Environmental Management Practices, Environmental Management Systems, Cost reduction, Hospitality, Malaysia.

Jel Classifications: L950; L940; L970.

Gopinath Sangaran, Lecturer, Sunway University. Malaysia.

Email: gopinaths@sunway.edu.my.

Ruth Sabina Francis, Lecturer (Corresponding Author), School of Hospitality, Tourism \& Events,

Taylor's University, no.1, Jalan Taylor's, Subang Jaya,47500, Selangor, Malaysia.

Email: ruthsabina.francis@taylors.edu.my.Tel:+60 356295000 / fax:+60 356295522.

\section{Introduction}

Environmental Management Practices (EMPs) in hotels has become a standard feature for many hotels. Hotels are using EMPs however, is the approach holistic? According to Pizam (2009), the approach can be further probed as to whether the approach by hotels could be a marketing strategy to attract tourist that are interested in this growing trend. This growing 
trend could be a temporary strategy where hotels adopt green practices like EMPs or the trend for being environmental friendly would become a permanent exercise in hotels. Some hotels tend to follow basic practices associated to being environmentally friendly. Some hotels tend to be unprincipled by simply declaring themselves as green and environmentally friendly. However, there are hotels that join marketing and central reservation groups that advertise or promote a hotel as being green or environmentally friendly for a small fee and memberships. To some extent in certain countries and states the law is very ambiguous or there is no legal definition towards green, environmentally friendly hotels. This eventually allows for hotels to use the term green or environmentally friendly without being verified (Heung et al., 2006). On the contrary there are groups of hotels that practice green systems and environmental management practices genuinely and conscientiously. These hotels are sincerely incorporating programs to being environmentally friendly by working with their local authorities, government bodies and non-government organizations to develop a criterion for certificate based programs. (Green Hotel Association, 2008).

The Green Hotel concept have been heavily promoted in Malaysia and as a result in 2014, ten (10) Malaysian hotels have been awarded with Asean Green Hotel Awards, The ten hotels are Shangri- La'sTanjungAru Resort and Spa Kota Kinabalu, Shangri-La's Rasa Ria Resort Tuaran and Nexus Karambunai Kota Kinabalu (Sabah); Riverside Majestic Hotel Kuching and Miri Marriot Resort and Spa (Sarawak); Mandarin Oriental Hotel, The Shangri-La Hotel and Renaissance Kuala Lumpur (Kuala Lumpur); The Andaman Langkawi (Kedah) and The Shangri-La's Rasa Sayang Resort and Spa (Penang). According to the Green Hotels Association (2014), green hotels refers to the pro-environmental lodging properties that implement various green practices such as saving water and energy, reducing the solid waste, and recycling and reusing the durable service items (e.g., bins, towels, etc.) to protect the earth. It is not only helping to conserve the green energy but the system acts as a marketing tool as well.

In this regard, Malaysia represents one of 12 mega diverse countries in the world, which have abundant of floras and faunas (Yusof \& Jamaludin, 2014). According to Malaysia Tourism Minister Y.B Dato Sri Dr Ng Yen Yen in 2012, "Malaysia is currently recognized by the UNWTO as the world 9th most travelled destination in the world. Tourism industry in Malaysia being the country's third largest foreign income contributor to the economyRM58.4 billion". The industry is targeted to generate RM168 billion in tourism receipts, attracting 36 million tourists by 2020 and creating an additional 500,000 jobs under the Malaysia Tourism Transformation Plan (MTTP) (Ibrahim, 2012). The Malaysian hotel industry has shown a growing interest and a grasp on "going green" and have implemented EMPs as a result larger group of hotels are involved in the practices (Wahab \& Pigram, 1997). Although there is plethora of literature on the barriers of implementing the EMPs and green operations (Chan 2008; Jauhari \& Rishi 2012; Kamalulariffin et al., 2013), there is a mix perception of the green movement and their practices among the hotels.

The area of this study is to comprehend the perceptions of the managerial staff in hotels towards EMPs and their needs towards such a system. The question is to what level are the hotels and their employees involved in the implementation and follow up process of the system or is it merely a management strategy of implementing a system to increase their brand rating, financial gains through long term savings or a part of their CSR corporate social responsibility initiatives.

\section{Literature Review}

\subsection{Environmental Management}

The literature on green approaches towards a greener environment are abundant (Oreja, et al., 2012; Peršić-Živadinov et al., 2010; Rahman et al., 2012; Scanlon, 2007). Over the years there have been many studies conducted in terms of perception and green practices in the area 
of Green Hospitality and environmental practices. Especially targeting a certain group of respondents where the research, studies the Managers perceptions on environmental management by (Kirk, 1998; Okeiyi et al., 2005; Prayag,G et al., 2010) and the tourists perception on the green operations by (Kelly et al., 2007; Sukkay, 2012).

Middleton and Hawkins (1998) describes environmental management systems as relating to the conduct of existing day-to-day business operations and is a useful label for the range of programs undertaken by a public or private sector organization to protect, enhance or reduce its impact on the environment. It is a corporate approach usually based on auditing procedures, which involves setting objectives, measurable targets; a detailed program and a monitoring and evaluation process (Hunter and Green, 1995). Environmental management systems are a continuous process by which the activities are monitored consistently and amended periodically to improve the system and reduce the negative environmental impacts. The other reasons being for environmental practices according to (Bansal \& Roth, 2000) for Green Hospitality is competitiveness and legitimation. Competitiveness as per of going green is to improve long term profitability by lesser expenses. Whereas legitimation is complying with the Government's environmental regulation to be in the market without being penalised (Rahman, 2012). The CondeNast Travellers' magazine conducted a readers' poll in September 1996, which revealed that $95 \%$ of travelers are concerned with the environmental conditions of their destinations (Moffitt \& Engeldrum, 1997).Within the hotel sector, the areas of concern for the environment include recycling of waste, waste management, clean air, energy and water conservation, environmental health, maintenance of permits such as building permits and compliance with legislation, purchasing policy and environmental education (Menza, 2006)

\subsection{Environmental Management in the Hotel Industry}

The tourism industry specifically the hotel industry is expected to grow by $3.3 \%$ per year reaching 1.8 billion by 2030 (UNWTO, 2015) and the industry offers limitless opportunities for any country economic growth (Francis \& Elangkovan, 2017). The rapid growth of the industry has increased the average income per capita and has also enhanced the products and the services (WTTC, 2016). Environmental management issues that have been of concern to the hotel industry have been recycling of waste, waste management, energy savings, water conservation, compliance with legislation, purchasing policy and environmental education (Forte, 1994; Kotler et al., 1999; Middleton \& Hawkins, 1998; Zhao \&Merna, 1992). According to (Nair \& Anantharajah, 2012), the green approaches concept of 3R's -'reuse, reduce and recycle" and the 2E's - 'energy and efficiency' are some of the areas that the hotels are emphasizing their practices on. Whereas there are multiple areas to be considered that can be worked on.

In spite of the growing popularity of environmental management in hotels, only larger hotels have been found to be at the forefront of environmental management (Alvarez Gil \& Cespedes Lorente, 2001; Mauforth \& Munt, 1998; Wahab \& Pigram, 1997). Mauforth and Munt (1998), claim that this is due to the fact that small- and medium-scale accommodation companies do not have the capital resources or internal arrangement structure to conduct environmental management. Facility age, chain affiliation and stakeholder environmental pressure have also been identified as impacting on hotels' environmental practices (Menza, 2006). Past literature, propose the implementation of environmental management practices that are prevalent in the hospitality industry and the most crucial practice being the financial sustainability. Pizman (2009) considers that many hospitality organizations are not interested in environmental sustainability for an ethical reason however the hospitality industry is investing in the environmental management practices for profitable reasons. In a business sense the main motive for running a business is to make profit and this has led to many 
hospitality organizations to adopt practices for the short term rather than planning for long term environmental management practices (Cotton, 2007).

Brown (2009) has suggested that many hospitality organizations operate with the main focus of achieving targets and financial gains and this has limited the implementation of environmental management practices. Kirk (1995) suggested that if the implementation of environmental management practices is to be successful the implementation should start from the top management. This would allow for the rest in the organization to follow suite. Consequently, creating motivation for all levels to follow a policy or strategy implemented in an organization. According to Kasim (2004), many management staffs are restricted to the basic thought of the environmental practice as they are not aware clearly of the technical know-how of the environmental management practices and their intention to be on the safe side in relation to environmental issues. However successful a system is to strive in an organization the workforce behind the practices needs a strong believes and motivation behind such system of practice. Here for instance: if the management decides to implement environmental management systems and the employees are not motivated by the need for such practice as the practice can be deemed too tedious and time consuming. The system would fail to sustain in the long term. The main concerns are the employees that are below the management levels, acceptance and perceptions towards implementation and practicing such systems. Hemmingway (2005) suggested that employee's values and organizational competitiveness can only explain environmental management practices with more visible financial returns. The lacking of a formal structure and empowerment in hotels appear to have established a context of "moral frustration" for employees that are interested in practicing environmental management systems. This feeling would lead employees in suppressing their ethical beliefs towards environmental systems and prioritize their efforts for achieving financial goals established by the organization. Ethical considerations of environmental management systems and employees input/feedback for creating an environmental framework would be necessary. Due to the research area being sparse in Malaysian hotel industry (Yusof \& Jamaludin, 2013), this study would attempt to highlight the employee's involvement in the process of environmental management practices in the selected five star hotels of Kuala Lumpur.

\section{Methodology}

The Qualitative approach was used to gather data and analysis was done to achieve results from the research. The methods of semi-structured interviews were applied which allowed for a two-way conversation and information was obtained orally. The intention of an in-depth semi structured interview was to provide the respondents the same stimuli so the information gathered from the respondents can be differentiated accurately. All respondents were employees of hotels in respective designations such as managers and supervisors from the operational departments and they were recruited from Industry linkages, LinkedIn networks and through other personal recommendations.

A total of twelve (12) respondents were identified in which two (2) respondents left the interview even before it could be completed due to the time constraints, three (3) respondents did not turn up and was non-compliance and the balance seven (7) respondents actively cooperated in the interview sessions, which lasted about one hour and twenty minutes per session respectively. Data saturation was reached with the (7) respondents and the analysis of the data commenced. The study included secondary data that were obtained from the previous studies done by the researchers from books, journal articles and websites.

\section{Results}

Colaizzi's Phenomenological method according to Sanders (2003) was deployed to analyze respondents' transcripts. The written transcripts were read several times to obtain a feel about 
them and significant phrases or statements that are directly linked to the environmental management system has been identified. From the significant phrases meanings are derived. From the derived meanings clustered themes are developed for the emergence of common themes. The results are then incorporated into the in-depth description of the study.

The respondents that were interviewed were from the operations department and had an average working experience of 5 to 10 years in the industry. All the respondents understood what EMPs were and they mentioned the hotels they work in practiced EMPs. The respondents agreed to the fact that EMPs were strongly deployed in their respective areas of operations in their hotels. The respondents provided examples such as 3R's (reduce, reuse and recycle), vermiculture, rainwater harvesting, solid waste management, eco sensor lightings and solar energy as practices that were commonly followed by the respondents in the hotel. The respondents highlighted that some of the EMPs are practiced as a Corporate Social Responsibility (CSR) where the hotels place up information ply cards for guest and organized weekly activities and events to promote EMPs.

Respondents 2, 3, 4, 6 and 7 highlighted that the main reason for such practice were a strategy for marketing and conservation of the environment. Respondent 1 and 5 strongly emphasized that the practice is not a marketing tool as many of their guest have very little knowledge of EMPs. Even with CSR practices not many guest and staff in the hotel are whole heartedly following such practices. In reality, their attitudes toward the environment and their community remain unchanged, or they are doing very little (Corporate Watch, 2001).

All respondents accepted that the EMPs practiced were a good practice that is required currently. All respondents were concerned about the holistic sense of the practice. Here they indicated that the main constrain would be the long term application and maintenance of such practices in day to day operations in the hotel. According to all respondent's consistency was the key factor for the hotel to continuously adapt to the practices. All respondents admitted that there were times where if possible they avoided following the practices to complete a task faster or when required to assist their team when they are under staffed. They agreed that such practices are for cost reduction and conservation reasons. According to Chan and Wong (2006) study in Hong Kong, hotels gained substantial cost savings from EMPs, reducing electricity, gas, fuel and water costs.

All respondents mentioned that cost cutting/ reduction measures for the hotel were the primary goal in applying these practices and the secondary goals were environmental concerns. The respondents shared their views on how environmental practices can help reduce cost in the long term and what can be done to improve the overall practices. However, for a new practice to be implemented at times there are cost involved and the management tend to avoid investments. The hotel itself is either built with little or no considerations towards the environmental requirements. To introduce environmental systems, the hotel would have to investment in refurbishments or different solutions to apply certain strategies and this is where the investment requirements can hinder an organization to move forward with investment for environmental practices. The current practices that are followed are cost effective or they require lesser investment. Studies have shown that irrespective of the size of the company, EMPs have enhanced financial benefits (Clemens, 2006) and progress the competitive advantage of the organization (Tari et al., 2010) and intangible advantages such as customer loyalty and improving reputation (Céspedes-Lorente et al., 2003). Respondent 2 highlighted that if the stakeholders and management believes in such a practice only then there would be a budget allocation yearly to enhance such environmental practices which would allow the continuity of the practices. These advantages meet the stakeholder's expectations (Ahmad, 2007) thereby they tend to support it positively.

All the respondents accepted that the awareness level is very low among the service providers and the consumers using the products. The marketing efforts for practices are not effective enough to suggest that the hotel is committed to environmental practices. The 
respondents even mentioned that the best and most effective manner to get recognized from such practice is to be endorsed by a body or association that would endorse the hotel like Green Globe or even ISO14001. However, many of the hotels where the respondents work have not been endorsed by such a body. Among all the respondents only respondent 2 whose hotel was awarded the first eco hotel in Asia by the accredited body. Further probing into the situation all respondents mentioned that since such practice has been enforced the hotels tend to follow practices that benefit their organizations. Government enforcement is one area the respondents mentioned should be stricter and the government could provide certain incentives that would drive forward the way to environmental practices and being sustainable. As proposed by Manaktola and Jauhari, (2007), governments can support organizations by creating a positive view of EMPs by proposing rewards and benefits.

\section{Conclusion, Implications, and Limitations}

In conclusion the need for EMPs in the context of the Malaysian hotel segment is very profound. However, there is a mix reaction between the players in the industry as there is a gap between staff and management beliefs, which was in accordance to the study by (Chan, 2008). The idea for such a practice is for the long term and the only way forward of such practices should start from the Government sectors and this would lead to the hotels in Malaysia to appreciate and even build the foundation of the hotel from such practices. Knowledge is the key to enhance the need for understanding EMPs and to ensure the community and industry are within the same wave length hence creating a smoother transformation to ensure EMPs are implemented and appreciated.

The research highlighted that the hotel industry is very much capable in achieving benefits by implementing and following EMPs. This finding was concordant with that of Yusof and Jamaludin (2013). However, the hotel industry in Malaysia must find a motive that would lead to accepting the concept and practices which would lead to a sustained business and the environment in the future. According to Manakotla and Jauhari (2007), generally guests are more than willing to stay in green hotels and are fully supportive of the various green practices but however they are not willing to pay extra for these services. The findings of this research would be resourceful to managers and department heads in hotels to know the perceptions of the employees before such massive implementations would be deployed. The findings all point that the employees who practice the various EMPs in the hotel are accomplishing it only for the sake of management compliance and are not wholly involved to conserve the energy. The findings of the study will also add in to the body of knowledge in the area of Environmental Management Practices in the hotel industry. This research could be extended to study the perceptions of the stake holders and the guests who patronize these hotels.

There were several limitations where we could not get many positive responses from the respondents to participate in the interviews. The other limitations were time factor for the interview as some respondents could not keep up with the interview time. The no shows of confirmed respondents for the interview and the willingness to participate were low for the study.

\section{References}

Ahmad ASA. (2007). The relationship between environmental management practices (EMP) and hotel performance: EMP drivers and the moderating role. Unpublished Exploratory, University Sains Malaysia.

Bansal, P., \& Roth, K. (2000). Why companies go green: A model of ecological responsiveness. Journal of Academy of Management, 43(4), 717-736. 
Brown, M. (1996) "Environmental policy in the hotel sector; "green" strategy or stratagem?" International Journal of Contemporary Management, Vol. 8, No. 3, pp.18-23.

Céspedes-Lorente J, Burgos-Jiménez Jd, Álvarez-Gil MJ. (2003). Stakeholders' environmental influence. An empirical analysis in the Spanish hotel industry. Scandinavian Journal of Management, 19(3), pp. 333-358.

Chan, E. S. W. (2008). "Barriers to EMS in the hotel industry." International Journal of Hospitality Management, 27(2): 187-196.

Chan E, \& Wong S., (2006). Motivations for ISO 14001 in the hotel industry. Tourism Management, 27(3), 481-492.

Clemens B. (2006). Economic incentives and small firms: does it pay to be green? Journal of Business Research, 59, 492-500.

Corporate Watch, (2001). Greenwash+10 The UN's Global Compact: Corporate Accountability and the Johannesburg Earth Summit, http://s3.amazonaws.com. Accessed on 13.09.2016.

Cotton, B. (2007) "We must find a balance of sustainability" Caterer \& Hotelkeeper, October, 2007, Vol. 197, pp. 32-33.

Green Hotel Association. (2008). What are green hotels. Retrieved May 10, 2008.

Francis, R. S., \& Elangkovan, N. A. (2017). Satisfaction towards internship programme and future career development for students in private higher education institutions: a research note. Asia-Pacific Journal of Innovation in Hospitality and Tourism, 6(2), pp. 69-74.

Green Hotel Association. (2008). What are green hotels. Retrieved May, 10, 2008.

Hemingway, C. A. (2005). Personal Values as a Catalyst for Corporate Social Entrepreneurship. Journal of Business Ethics, 60(3), pp. 233-249.

Ibrahim, F. (2012). Buletin 1 MOTOUR. U. K. Korporat. putrajaya, Kementerian Pelancongan Malaysia 3.

Jauhari, V., \& Rishi, M. (2012). Challenges faced by the hospitality industry in India: an introduction. Worldwide Hospitality and Tourism Themes, 4(2), 110-117.

Kamalulariffin, N. S., Nabiha, S., Khalid, A., \& Wahid, N. A. (2013). The barriers to the adoption of environmental management practices in the hotel industry : a study of Malaysian hotels. Business Strategy Series, 14(4), 106-117.

Kasim, A. (2004). Socio-Environmentally Responsible Hotel Business: Do Tourists to Penang Island, Malaysia Care? Journal of Hospitality \& Leisure Marketing, 11(4), pp. 5-28.

Kelly, J., Wolfgang, H., Peter, W., \& Krista, E. (2007). Stated preferences of tourists for ecoefficient destination planning options. Journal of Tourism Management, 28, pp. 377390.

Kirk, D. (1998). Attitudes to environmental management held by a group of hotel managers in Edinburgh. Journal of HospitalityManagement, 17, pp. 33-47.

Manaktola, K. and Jauhari, V. (2007). Exploring consumer attitude and behaviour towards green practices in the lodging industry in India. [Research paper]. International Journal of Contemporary Hospitality Management, 19(5), 364-377.

Middleton, V. T., \& Hawkins, R. (1998). Sustainable tourism: A marketing perspective. Routledge.

Nair, V., \& Anantharajah, S. (2012). A green makeover for our Hotels. Quartely DOE update on Environment, Development \& Sustainability, 2, pp. 10-12.

Oreja-Rodríguez, J. R., \& Armas-Cruz, Y. (2012). Environmental performance in the hotel sector: The case of the Western Canary Islands. Journal of Cleaner Production, 29(30),pp. 64-72.

Peršić-Živadinov, \& Blažević. B. (2010). Sustainable hotels: Sustainable life-cycle practice in Croatian hotels. Conference Proceedings: Tourism \& Hospitality industry 2010 - New Trends in Tourism and Hospitality Management, pp. 161-177 
Pizman, A. (2009) "Green Hotels: A fad, ploy or fact of life" International Journal of Hospitality Management, Vol.28, No.1, p. 1.

Prayag, G., Dookhony-Ramphul, K., \& Maryeven, M. (2010). Hotel development and tourism impacts in Mauritius: Hoteliers'perspectives on sustainable tourism. Development Southern Africa, 27(5), pp. 697-712.

Rahman, I., Dennis, R., \& Stefani, S. (2012). How green are North American Hotels? An exploration of low-cost adoption practices. International Journal of Hospitality Management, 31, pp. 720-727.

Sanders, C. (2003). Application of Colaizzi's method: Interpretation of an auditable decision trail by a novice researcher. Contemporary Nurse, 14(3), pp. 292-302.

Scanlon, N. L. (2007). An analysis and assessment of environmental operating practices in hotel and resort properties. Journal of Hospitality Management, 26, 711-723.

Sukkay, S., \& Sahachaisaeree, N. (2012). A study of tourists' environmental perceptions of the functional design of popular Resorts in Chiang Rai Province. Social and Behavioral Sciences, 50,114.

Tarí JJ, Claver-Cortés E, Pereira-Moliner J, Molina-Azorín JF. (2010). Levels of quality and environmental management in the hotel industry: their joint influence on firm performance. International Journal of Hospitality Management, 29(3), pp. 500-510.

UNWTO. (2015). Annual Report. Retrieved from http://cf.cdn.unwto.org/sites/all/files/pdf.

World Trade Organization. (2014). Annual Report. Retrieved from https://www.wto.org/english.

Yusof, Z. B., \& Jamaludin, M. (2013). Green Approaches of Malaysian Green Hotels and Resorts. Procedia Social and Behavioral Sciences, 85, pp. 421-431.

Yusof, Z. B., \& Jamaludin, M. (2014). Barriers of Malaysian green hotels and resorts. Procedia-Social and Behavioral Sciences, 153, pp. 501-509. 